\title{
The Effect of Job Satisfaction, Perceived Organizational Support, and Organizational Climate with Organizational Citizenship Behavior in PT XYZ's Employee
}

Annisa Nabilla $^{1 *}$, Setyo Riyanto ${ }^{2}$

${ }^{1}$ Master of Management, Mercubuana University, Jakarta, Indonesia

${ }^{2}$ Lecture of Postgraduate, Mercubuana University, Jakarta, Indonesia

DOI: $10.36348 /$ sjhss.2020.v05i08.006 $\quad$ | Received: 12.08 .2020 | Accepted: 20.08 .2020 | Published: 26.08 .2020

*Corresponding author: Annisa Nabilla

Abstract

A company increases profits every year in order to keep reaching a larger target. It can be reached if each employee is having an Organizational Citizenship Behavior (OCB). The aims of this study are to measure and analyze the influence of job satisfaction, Perceived Organizational Support (POS), and organizational climate through OCB of the employee on employees in an outsourcing company Jakarta. The population of this study was all employees in the outsourcing company, which were 72 respondents. The sampling technique used in this study was saturated sampling with all employees for the object. This study used a linear regression method to analyze data. The finding of this study was job satisfaction, POS, and organizational climate variables have significant correlations to OCB. This study also showed the most variable that influencing OCB was job satisfaction.

Keywords: Job satisfaction, POS, Organizational Climate, and OCB.

Copyright @ 2020: This is an open-access article distributed under the terms of the Creative Commons Attribution license which permits unrestricted use, distribution, and reproduction in any medium for non-commercial use (NonCommercial, or CC-BY-NC) provided the original author and source are credited.

\section{INTRODUCTION}

Human resources are one of the most essential assets of every organization. Organizational success will depend on the role of human resources in achieving its goals. For this reason, human resources need proper management. The management of human resources is not only the responsibility of the human resources development division, but the leader of this organization needs to take it as a responsibility too. Suppose the organization can manage the company well, employees will also be willing to show their contribution in a higher work environment supporting their role in the organization or also called Organizational Citizenship Behavior (OCB).

Before conducting research, the researchers did a pre-survey to determine the OCB level of employees at PT XYZ. In the pre-survey data, employees' question included initiatives to help colleagues, a willingness to work overtime and accept any changes that occur in working conditions. The presurvey results at PT XYZ concluded that 54\% of employees did not indicate that they have OCB. Besides, researchers surveyed 30 employees of PT XYZ to find out what variables influenced the level of OCB at PT XYZ. After conducting the survey, it found that the employees of PT XYZ still perceived that they had not received the appropriate salary and bonus. That was one of the dimensions of job satisfaction. Moreover, the employees of PT XYZ did not feel that the company considered their welfare and assumed that the applied regulations were not sufficient. That was included in the dimension of POS. PT XYZ employees assumed that the regulations applied were not evenly distributed. These aspects covered in the organizational climate dimension.

\section{THEORETICAL REVIEW \\ Organizational citizenship behavior}

According to Hapsari \& Riyanto [1] OCB is one tools which can identify the behavior of employees who want to contribute beyond the demands of their job roles. Besides, according to Bhatti, Ju, Akram, Bhatti, Akram, and Bilal [2], OCB is the behavior of employees who are no longer part of their work but go beyond what is assigned by the company. However, in doing the work the employee feels voluntary or does not get an award. Employees who display OCB behavior will act like an organization's "citizen." OCB is positively related to sustained performance. OCB can 
also be a contributor to organizational practices and outcomes [3]. OCB has officially developed five dimensions of OCB, namely altruism, conscientiousness, courtesy, civic virtue, and sportmanship [4].

\section{JOB SATISFACTION}

Job Satisfaction is one factor that can support the achievement of organizational success. Job satisfaction is still an essential and exciting issue to be studied. That is because there is a significant influence between the benefits of individuals, organizations, and society. Satisfaction and dissatisfaction felt by employees when working become part of the dynamics organization [5]. According to Tafzal Haque et al., [6], job satisfaction is a state of positive or pleasant feeling from employee work experience. There are two type of factor of job satisfaction in intrinsic and extrinsic. The intrinsic factor is a set property of opportunities, skills, abilities, creativity in working, and positive feedback to the upper level of the firm. Extrinsic factor are supporting environment from the companion, leaders, and supervisor. They include of promotional packages, job shifting, job enrichment, compensation and rewards [7].

\section{Organizational Climate}

According to Viswanathan et al., [8], organizational climate measures individual perception or emotion towards a business. Darmajaya [9] said the organizational climate is the nature of the work environment or psychological environment felt by workers or members of the organization and is considered capable of influencing workers' attitudes and behavior towards their work. Based on the theory, the organizational climate of individual perceptions or emotions towards a business both from the work environment and the perception environment. There are six dimensions of organizational climate namely, organizational structure, achievement standards, responsibilities, awards, support, and commitment [7].

\section{RESEARCH METHOD AND ANALYSIS Research Method}

This study is a qualitative study with primary data in the form of surveys. This research was designed to gain understanding, explain and analyze the correlation between the independent variables and the dependent variable. This research emphasizes descriptive research, aiming to provide a complete picture of the phenomena that occur in XYZ. The population was 72 employees of PT XYZ. While the sample in this study was nonprobability sampling with a saturated sample because the total population in this study used an entire population of 72 people to be sampled. Data Analysis Methods used in this study included descriptive statistics, research instrument tests, classic assumption tests, multiple regression analysis and hypothesis testing. The data in this study were processed with the Statistical Package for Social Science (SPSS) version 25.

\section{The Results of Analysis and Discussion}

From the results of descriptive statistical analysis in this study, it was found that the sample perception of job satisfaction, POS, and organizational climate towards OCB with a mean value of 3.20 , as well as the sample perception of job satisfaction (3.13), POS (3.05), and Organizational Climate (3.64). Hypothesis Testing In statistical data testing, the data used were derived from 72 questionnaires. The data is then processed using the SPSS version 25.0 program

Tabel-1: Multiple Regression Linear OCB (Y)

\begin{tabular}{|c|c|c|c|c|c|c|}
\hline \multicolumn{7}{|c|}{ Coefficients $^{\mathrm{a}}$} \\
\hline \multirow{2}{*}{\multicolumn{2}{|c|}{ Model }} & \multicolumn{2}{|c|}{$\begin{array}{l}\text { Unstandardized } \\
\text { Coefficients }\end{array}$} & \multirow[t]{2}{*}{$\mathbf{t}$} & \multirow[t]{2}{*}{ Sig. } & \multirow[t]{2}{*}{ Remarks } \\
\hline & & $\mathbf{B}$ & Std. Error & & & \\
\hline \multirow[t]{4}{*}{1} & (Constant) & 1.727 & 0.145 & 11.915 & 0.000 & \\
\hline & Job satisfaction & 0.302 & 0.036 & 8.392 & 0.000 & $\begin{array}{l}\text { Positive Relationship and } \\
\text { Significant }\end{array}$ \\
\hline & $\begin{array}{l}\text { Perceived } \\
\text { Organizational Support }\end{array}$ & 0.112 & 0.035 & 3.219 & 0.002 & $\begin{array}{l}\text { Positive Relationship and } \\
\text { Significant }\end{array}$ \\
\hline & Organizational Climate & 0.195 & 0.045 & 4.387 & 0.000 & $\begin{array}{l}\text { Positive Relationship and } \\
\text { Significant }\end{array}$ \\
\hline \multicolumn{6}{|c|}{ a. Dependent Variable: OCB } & \\
\hline
\end{tabular}




\begin{tabular}{|c|c|c|c|c|c|c|}
\hline \multicolumn{7}{|c|}{ Table-2: Correlation Matrix } \\
\hline \multirow[t]{2}{*}{ Variable } & \multirow[t]{2}{*}{ Dimension } & \multicolumn{5}{|c|}{ OCB (Y) } \\
\hline & & $\begin{array}{c}4.1 \\
\text { Altruisme } \\
\end{array}$ & $\begin{array}{c}4.2 \\
\text { Constiousness } \\
\end{array}$ & $\begin{array}{c}4.3 \\
\text { Sportmanship } \\
\end{array}$ & $\begin{array}{c}4.4 \\
\text { Courtesy } \\
\end{array}$ & $\begin{array}{c}4.5 \text { Civic } \\
\text { Virtue }\end{array}$ \\
\hline \multirow{6}{*}{$\begin{array}{c}\text { Job Satisfaction } \\
(\mathrm{x} 1)\end{array}$} & 1.1 The Job & 0.448 & 0.554 & 0.481 & 0.449 & $0 . .380$ \\
\hline & 1.2 Reward & 0.506 & 0.538 & 0.420 & 0.456 & 0.286 \\
\hline & 1.3 Promotion & 0.535 & 0.617 & 0.463 & 0.481 & 0.351 \\
\hline & 1.4 Supervision & 0.420 & 0.511 & 0.465 & 0.446 & 0.361 \\
\hline & 1.5 Coworkers & 0.442 & 0.508 & 0.448 & 0.527 & 0.409 \\
\hline & $\begin{array}{l}1.6 \text { Work } \\
\text { Environments }\end{array}$ & 0.414 & 0.535 & 0.479 & 0.529 & 0.431 \\
\hline \multirow[t]{3}{*}{$P O S(\mathrm{x} 2)$} & 2.1 Justice & 0.268 & 0.331 & 0.246 & 0.329 & 0.279 \\
\hline & $\begin{array}{l}\text { 2.2 Superior } \\
\text { support }\end{array}$ & 0.190 & 0.276 & 0.233 & 0.393 & 0.227 \\
\hline & $\begin{array}{l}2.3 \text { Work } \\
\text { Condition }\end{array}$ & 0.362 & 0.381 & 0.388 & 0.512 & 0.364 \\
\hline \multirow{9}{*}{$\begin{array}{l}\text { Organizational } \\
\text { Climate }(\mathrm{x} 3)\end{array}$} & 3.1 Structure & 0.334 & 0.326 & 0.315 & 0.305 & 0.305 \\
\hline & 3.2 Responsibilit & 0.398 & 0.397 & 0.378 & 0.365 & 0.335 \\
\hline & 3.3 Appreciation & 0.414 & 0.355 & 0.342 & 0.480 & 0.311 \\
\hline & $\begin{array}{l}3.4 \text { Risk and } \\
\text { challenge }\end{array}$ & 0.404 & 0.324 & 0.273 & 0.482 & 0.340 \\
\hline & 3.5 Warmth & 0.415 & 0.426 & 0.328 & 0.485 & 0.361 \\
\hline & 3.6 Support & 0.260 & 0.285 & 0.308 & 0.343 & 0.310 \\
\hline & $\begin{array}{l}\text { 3.7 Performance } \\
\text { Standard }\end{array}$ & 0.262 & 0.329 & 0.276 & 0.324 & 0.346 \\
\hline & 3.8 Conflict & 0.137 & 0.259 & 0.276 & 0.256 & 0.294 \\
\hline & $\begin{array}{l}\text { 3.9 Personal } \\
\text { Identity }\end{array}$ & 0.272 & 0.322 & 0.281 & 0.381 & 0.363 \\
\hline
\end{tabular}

The interpretation and testing of the hypothesis $(\mathrm{H})$ in table 1 and table 2 is as follows:

$$
\mathrm{Y}=1,727+0,302 \mathrm{X} 1+0,112 \mathrm{X} 2+0,195 \mathrm{X} 3+\mathrm{e}
$$

There is an influence of Job Satisfaction (X1) partially on $\mathrm{OCB}(\mathrm{Y})$

Table 1 above shows that the relationship between Job Satisfaction (X1) and OCB (Y) is significant with a t-test of 8.339 (t-count $>\mathrm{t}$ table $(\mathrm{df}=$ $68)=1.99)$ and the Sig. $=0,000$. The coefficient value is positive that is equal to 0.302 which indicates that the direction of the relationship between Job Satisfaction (X1) with OCB is positive at $30.2 \%$. Thus the H1 hypothesis in this study which states that "Job Satisfaction (X1) has a significant effect on OCB (Y) Employees" is accepted. The greatest correlation value between the dimensions in the Job Satisfaction (X1) variable and the OCB (Y) variable is X1.3 dimension Promotion with the Y2 dimension. Consciousness is 0,617 , and is included in the category of strong relationship level. This explains that the dimension X1.3 Promotion in the Job Satisfaction variable is indispensable to support the increase in OCB (Y) especially in the Consciousness dimension

\section{There is an effect of Perceived Organizational Support (X2) on OCB (Y) partially}

Table 1 above shows that the relationship between Perceived Organizational Support (X2) and OCB (Y) is significant with a t-count of 3.219 (t-count $(\mathrm{df}=68)>1.99)$ and a Sig. $=0.002$. The coefficient value is positive, equal to 0.112 , which indicates that the direction of the relationship between Perceived Organizational Support (X2) with OCB is positive at $11.2 \%$. Thus the H2 hypothesis in this study, which states that "Perceived Organizational Support (X2) has a significant effect on OCB (Y) Employees", is accepted. The greatest correlation value between the dimensions in the Perceived Organizational Support (X2) variable to the OCB (Y) variable is X2.3 Working Conditions with the Y4 dimension. Courtesy is 0.512 , and belongs to the medium level of relationship category. This explains that the dimension X2.3 Working Conditions in the Perceived Organizational Support variable is needed for each increase in OCB (Y) especially in the Courtesy dimension.

\section{There is an influence of Organizational Climate (X3) on OCB (Y) partially}

Table 4.15 above shows that the relationship between Organizational Climate (X3) and OCB (Y) is significant with a t-test of 4.387 (t-count $(\mathrm{df}=68)>$ 1.99 and Sig value $=0.000$. The coefficient value is positive, that is 0.195 , which shows that the direction of the relationship between Organizational Climate (X3) and OCB is positive at $19.5 \%$. Thus the hypothesis H3 in this study, which states that "Organizational Climate (X3) has a significant effect on OCB (Y) Employees", is accepted. The greatest correlation value between the dimensions in the Organizational Climate variable (X3) 
with the OCB variable (Y) is the X3.5 dimension of Warmth with the Y4 dimension. Courtesy is 0.485 , and belongs to the medium level of relationship category. This explains that the dimension X3.5 Warmth in the Organizational Climate variable is required for any increase in OCB (Y) especially in the Courtesy dimension.

\section{Job Satisfaction, Perceived Organizational Support, and Organizational Climate simultaneously influence OCB}

Based on the results of the simultaneous significance test (f test) in table 4.14 above shows the F-calculated value of 65.240 (F-count $>$ F-table $(n=72$, and $\mathrm{k}=3=2.74$ ) and Sig. $=0.000$, which shows that the Job Satisfaction variable (X1), the Perceived Organizational Support (X2) variable, and the Organizational Climate variable (X3) together have a significant effect on the OCB variable (Y). Thus, the hypothesis $\mathrm{H} 4$ in this study, which states that "Job Satisfaction, Perceived Organizational Support, and Organizational Climate simultaneously influence OCB," is accepted.

\section{DISCUSSION}

\section{Analysis of the Effect of Job Satisfaction on OCB}

Based on the results of the study, job satisfaction influenced OCB. This finding is consistent with the results of the studies by [10-12, 3, 13] which found that job satisfaction influenced OCB in employees. That was shown when the employees of PT XYZ have excellent job satisfaction, the OCB will get better. On the contrary, if PT XYZ employees do not have excellent job satisfaction, OCB employees will not be good. In this study the promotion dimension on job satisfaction variables strongly influenced the consciousness dimension on OCB variables. Thus, if PT $\mathrm{XYZ}$ has a sound promotion system, or if employees get a promotion it will increase consciousness, namely employee discipline when working and it will affect OCB.

\section{Analysis of the Effect of Perceived Organizational Support on OCB}

The results showed there was an influence between POS and OCB. This finding is consistent with [11] that said there is influence between those two variabel. The working conditions dimension had the most substantial influence on one of the OCB variables, namely courtesy. In the POS variable, working conditions described the organization's recognition of employee contributions. Whereas courtesy is an employee's courtesy behavior. Therefore, if the company is willing to recognize employee contributions, this will increase employee behavior when working and will impact OCB employees of PT XYZ.
Analysis of the Effect of Organizational Climate on OCB

The results of this study indicated that there was an influence between organizational climate and OCB. This finding are in line with the research of [7, $14,15]$, which also said there was an influence between organizational climate and OCB. Thus, the better the organizational climate at PT XYZ, the higher the OCB of the employee will be. The warmth of the organizational climate variable had a moderate relationship with the OCB variable's courtesy dimension. In organizational climate variables, warmth referred to interpersonal relationships in organizations. Thus, if the interpersonal relationship at PT XYZ is good enough for each employee, it will show excellent manners that will increase OCB.

Simultaneous Analysis of the Effect of Job Satisfaction, Perceived Organizational Support, and Organizational Climate on OCB

Job satisfaction, POS, and organizational climate simultaneously influenced OCB employees of PT XYZ. By increasing, the employee's job satisfaction through a transparent job promotion system will improve the OCB of PT XYZ employees. From the POS side can be improved through the ability of organizations to recognize and appreciate the contributions made by employees. Besides, when viewed from organizational climate variables, employees' interpersonal relations can also be improved to create a synergistic relationship. These three things will increase OCB employees of PT XYZ.

\section{CONCLUSION AND SUGGESTION}

\section{Conclusion}

Based on the results of previous studies and discussions, several conclusions can be made as follows:

1. Job Satisfaction has an influence on OCB. The promotion variable has a considerable influence on OCB, especially the consciousness variable, namely employee discipline. Thus, if the company has a sound promotion system, it will increase employee discipline in work, such as the responsibility in completing work to be willing to answer the call even though not on working hours. This Research in line with

2. Perceived Organizational Support has an influence on OCB, especially on the variable work conditions that had the most significant influence on courtesy. Working conditions include the way organizations value each employee's contribution. Meanwhile, courtesy is the availability of employees in avoiding conflicts such as the ability to accept changes that occur in the company. Therefore, if the company can appreciate excellent contributions to employees, then employees will always respect every rule or change in the company. 
3. Organizational climate has an influence on OCB, especially on the warmth variable which had the most substantial influence on one of the OCB variables, namely courtesy. This study concluded that if the company has a sympathetic or fairly good interpersonal relationship between employees, both fellow staff and between superiors and subordinates, will make employees able to respect every rule and adapt to changes in the company.

4. Job Satisfaction Variables, Perceived Organizational Support, and Organizational Climate together have an influence on OCB.

\section{Suggestions}

Based on the results above, the suggestions to complete this study are as follows:

1. The next researcher is expected to be able to involve other variables that have a strong influence in shaping OCB besides job satisfaction, POS, and organizational climate such as work commitment, work motivation, and leadership style. In future studies, data analysis methods will be carried out using tools other than SPSS such as SEM PLS, Lisrel, and others. In subsequent studies, it can also retrieve data from different industries apart from outsourcing companies.

2. There is an influence between job satisfactions on OCB. Thus, the researchers suggest that companies pay attention to some shows. The results of this study indicate that job satisfaction has a positive and significant effect on OCB. In this study, the dimensions of promotion on job satisfaction variables have a healthy relationship on the consciousness dimension on OCB variables. Thus, suggestions for the company are expected to carry out a promotion system that is quite clear to employees. At present, in one of the outsourcing companies, there is no clarity regarding its promotion. Employees often remain in the same position for quite a long time. Besides, sometimes employees also get promotions but are only given additional duties and responsibilities, without any training or adjustments in terms of salary. This makes employees when they get a promotion even feel burdened. Based on the previous study, it is expected that companies engaged in the field of outsourcing will carry out a clear promotion system. First, do a mapping of employees in which employees need to be developed or given a promotion. Then, do training for employees who will get a promotion so that the employee becomes better prepared to hold a higher position. The form of training provided later needs to be analyzed again. Depending on the needs of the employee. When employees are ready to be promoted, it should be done formally and in writing. Employees also get adjustments to compensation and benefits based on new positions given. When the promotion system in the outsourcing company is transparent and directed, it will make employees increase their discipline in their work. They feel that every job they do will get good feedback from the company, one of which is the opportunity to get a promotion.

3. The results of this study indicate that POS has an influenced OCB, especially between the dimensions of working conditions against courtesy. The working conditions of the POS variable mean the way the company appreciates each employee's contribution. Meanwhile, courtesy is the willingness of employees to avoid problems. At present, there is no evidence of the way the company appreciates employee contributions. Thus, it is expected that the company is able to appreciate employees' work such as providing overtime pay, incentives when employees can achieve targets, and a bonus system that is quite clear and in line with the employee's performance. It will also be more effective if implemented employee of the year to increase employee OCB. When employees feel that each of his contributions is valued, they will be willing to work, even exceed their role and always accept changes in the company.

4.

This study also shows the influence of organizational climate on OCB. The warmth of the organizational climate variable has the highest influence on the dimensions of courtesy on the OCB variable compared to other variables. The company suggests that it should generate warmth based on interpersonal relationships between employees of fellow staff and superiors. A leader has a vital role in creating warmth within the organization. Warmth can be formed by holding briefings every morning, involving employees to work in teams, conducting weekly, monthly or annual evaluations. Besides, superiors are expected to establish good relations with team members, so employees are not reluctant to discuss especially in the scope of work. The management and human resources can also facilitate through gathering, team building training, involving in the committee in an event and others. The company is also expected to communicate any existing regulations and changes transparently. When there is warmth in the company, the employee will feel comfortable in the company so he will try to understand every change that occurs in the company. Employees will also participate in creating warmth in the company by avoiding conflict.

\section{REFERENCES}

1. Diana, R., \& Hapsari, C. (2020). The Reactions over Organizational Citizenship Behavior ( OCB) that viewed from Transformational Leadership , Organizational Culture, and Compensation 
Variables, 5(5), 1977-1984.

2. Bhatti, M. H., Ju, Y., Akram, U., Bhatti, M. H., Akram, Z., \& Bilal, M. (2019). Impact of participative leadership on organizational citizenship behavior: Mediating role of trust and moderating role of continuance commitment: Evidence from the pakistan hotel industry. Sustainability (Switzerland), 11(4). https://doi.org/10.3390/su11041170

3. Qiu, Y., Lou, M., Zhang, L., \& Wang, Y. (2020). Organizational citizenship behavior motives and thriving at work: The mediating role of citizenship fatigue. Sustainability (Switzerland), 12(6). https://doi.org/10.3390/su12062231

4. Gao, W. (2020). Gender and Organizational Citizenship Behavior, 415(Isss 2019), 25-29. https://doi.org/10.2991/assehr.k.200312.006

5. Riyanto, S., \& Panggabean, M. (2020). The Impact of Leadership, Organizational Culture and Organizational Climate on Employee Job Satisfaction (Case Study: PT Garuda Indonesia (Persero) Tbk). January. https://doi.org/10.2991/aebmr.k.200205.007

6. Tafzal Haque, A. K. M., Uddin, M. A., Easmin, R., \& Sohel, S. M. (2019). Job Satisfaction and Citizenship Behavior: A Mediating Effect of Organizational Commitment. Organizacija, 52(3), 236-249. https://doi.org/10.2478/orga-2019-0015

7. Wahyu, A., Tentama, F., \& Diah Sari, E. Y. (2019). The role of servant leadership and organizational climate on organizational citizenship behavior with job satisfaction as mediator. International Journal of Scientific and Technology Research, 8(10), 1134-1141.

8. Viswanathan, R., Sarath Lal, N., Prasad, V., \& Parveen, J. (2019). Relationship of leadership and organizational climate indispensable element to facilitate employee engagement. International Journal of Recent Technology and Engineering, $8(2$ Special Issue 4), 429-434. https://doi.org/10.35940/ijrte.B1084.0782S419
9. Darmajaya, J. B. (2017). Pengaruh Iklim Organisasi Terhadap Kinerja Karyawan Pada Pt. Bank Danamon Simpan Pinjam Unit Metro. Jurnal Bisnis Darmajaya, 3(2), 163-172.

10. Mohapatra, M. Das, Satpathy, I., \& Patnaik, B. C. M. (2019). Impact of dimensions of organizational citizenship behaviour on job satisfaction in information technology sector. International Journal of Innovative Technology and Exploring Engineering, 8(12), 2503-2508. https://doi.org/10.35940/ijitee.L3435.1081219

11. Fiernaningsih, N., Nimran, U., Raharjo, K., \& Arifin, Z. (2019). The role of work-life balance, organizational pride, and job satisfaction on organizational citizenship behaviour: Case study on hospitality employees in Indonesia. International Journal of Innovation, Creativity and Change, 8(4), 73-94.

12. Zahran, W. (2018). Investigating the Relationship between Job Satisfaction and Organizational Citizenship Behavior among Beni Suef Cement Company Employees. SSRN Electronic Journal, 6(5). https://doi.org/10.2139/ssrn.2795519

13. Sabahi, A. H., \& Sanai Dashti, N. (2016). The effect of emotional intelligence and job satisfaction on organizational citizenship behavior. Management Science Letters, 97(Piceeba), 475480. https://doi.org/10.5267/j.ms1.2016.6.001

14. Romaiha, N. R., Maulud, F. S. F., Ismail, W. M. W., Jahya, A., Fahana, N., \& Harun, A. (2019). The Determinants of Organizational Citizenship Behaviour (OCB). International Journal of Academic Research in Business and Social Sciences, 9(8), 124-133. https://doi.org/10.6007/ijarbss/v9-i8/622

15. Bukhari, I., \& Kamal, A. (2017). Perceived organizational support, its behavioral and attitudinal work outcomes: Moderating role of perceived organizational politics. Pakistan Journal of Psychological Research, 32(2), 581-602. 